\title{
Identification of the causal agent of "pata seca" in pepper crop production areas of Ecuador
}

\author{
Miguel Angel Quilambaqui Jara ${ }^{1}$; Antonio Carlos Maringoni²;
}

${ }^{1}$ Escuela Superior Politécnica del Litoral, ESPOL, Facultad de Ingeniería Mecánica y Ciencias de la Producción, Campus Gustavo Galindo Km. 30.5 Vía Perimetral, P.O. Box 09-01-5863, Guayaquil, Ecuador. ${ }^{2}$ Faculdade de Ciências Agronômicas/UNESP, CEP 18610.307, Botucatu, SP, Brasil Autor para correspondência: M.A. Quilambaqui Jara (mquilamb@espol.edu.ec)

Data de chegada: 21/05/2017. Aceito para publicação em: 15/08/2017.

$10.1590 / 0100-5405 / 180291$

\section{ABSTRACT}

Quilambaqui Jara, M.A.; Maringoni, A.C. Identification of the causal agent of "pata seca" in pepper crop production areas of Ecuador. Summa Phytopathologica, v.44, n.4, p.338-343, 2018.

Cultivation of pepper (Capsicum annuum L.) has high economic relevance in Ecuador. Although the planted area is approximately 5704 ha, its productivity is low $\left(3.17 \mathrm{t} \mathrm{ha}^{-1}\right)$ relative to other countries in the region. In recent years, the spread and the development of a disease that leads the plant to death, known by farmers as "pata seca" and occurring in production zones located in Guayas and Santa Elena Provinces, have caused great economic losses. The aim of this study was to evaluate the effect of "pata seca" on commercial pepper crops during 2013 and 2014 and to identify the causal agent of such disease. Twenty-three farms were visited, where samples and data were collected. "Pata seca" was detected in 79.2\% samples, and 53.6\% plants had symptoms of this disease. Analysis of the samples collected in 2013 and 2014 indicated that the predominant fungi were Sclerotium rolfsii $(31.17 \%$, $49.64 \%$ ) and Fusarium spp. (29.29\%, 32.37\%), respectively. Pathogenicity tests confirmed that $S$. rofsii is the major causal agent.

Keywords: Fusarium spp, Sclerotium rolfsii, associated fungi, pepper disease, "pata seca"

\section{RESUMO}

Quilambaqui Jara, M.A.; Maringoni, A.C. Identificação do agente causal da "pata seca" em áreas de produção de pimentão no Equador. Summa Phytopathologica, v.44, n.4, p.338-343, 2018.

A cultura do pimentão (Capsicum annuum L.) tem alta importância econômica no Equador. Apesar da área platanda ser próxima de 5704 ha, a produtividade é baixa $\left(3,17 \mathrm{th}^{-1}\right)$ em relação aos países da região. Nos últimos anos, a propagação e o desenvolvimento de uma doença que causa a morte da planta, conhecida pelos agricultores como "pata seca", que ocorre nas áreas de produção situadas nas províncias de Guayas e Santa Elena, tem causado elevadas perdas econômicas. Objetivouse avaliar efeito da doença "pata seca" em plantios comerciais de pimentão durante os anos de 2013 e 2014 e identificar o agente causal da enfermidade. Visitaram-se 23 fazendas, onde foram coletadas amostras e dados. A "pata seca" foi constatada em $79,2 \%$ das amostras, com $53,6 \%$ das plantas apresentando sintomas da doença. Detectou-se nas análises das amostras coletadas em 2013 e 2014, como predominantes os fungos Sclerotium rolfsii $(31,17 \%, 49,64 \%)$ e Fusarium spp. $(29,29 \%, 32,37 \%)$ respectivamente. Nos testes de patogenicidade confirmaram que o $S$. rofsii é o principal agente causal.

Palavras-chave: Fusarium spp, Sclerotium rolfsii, fungos associados, doença do pimentão, "pata seca"

Pepper (Capsicum annuum L.) cultivation is important for the Ecuadorian population since it can be used fresh and processed. This vegetable is part of the diet in Ecuador. From 1997 to 2001, pepper production has increased by $188 \%$ for its economic relevance and price (16). Currently, its production is approximately 5704 ha (6). The provinces showing higher production are Guayas, Santa Elena, Manabi, Chimborazo, Loja and other places in the Andean region INEC (23).

According to the national register AGROCALIDAD (3), pepper sowing and production include 13 cultivars between varieties and hybrids. The most relevant ones for producers are: Irazú Largo, Yolo Wonder, Cubanelle, Quetzal, Nathalie, Salvador, Marcato F1, Amanda, Dahra, Martha and Magali. Pepper sowing takes place in zones with optimal temperature between 25 and $31^{\circ} \mathrm{C}$, where germination and vegetable development are favored. It adapts well up to 1.800 masl but higher heights could affect the crop development (19).

Although pepper is grown in Ecuador, its productivity $\left(3.17 \mathrm{t} \mathrm{ha}^{-1}\right)$ is low compared to other countries in the region (12). In the latest years, dissemination of "pata seca" disease has been detected, affecting the provinces of Guayas and Santa Elena. It starts with a brown spot on the plant stem base, near the soil, which expands as fungal structures, similar to a white mycelium and structures known as sclerotia. The diseased plants remain in the field where they wilt and die. Pepper producers at that zone have reported production loss in previous years (34).

According to the symptomatology, it is a new disease in pepper production fields at the coastal zone of Ecuador caused by Sclerotium rolfsii (teleomorph: Athelia rolfsii), which has also been reported in other countries and continents. The causal agent produces diseases in tropical and subtropical regions to more than 500 host plants, such as: apples, potatoes, tomatoes, peanuts, ornamental plants, herbaceous plants and trees (27).

Other fungi associated with this symptomatology is Fusarium spp. which causes pepper wilt and was first reported in 1989 by Revelli (35), 
as cited by Huang and Vallad (17). According to the description of the principal diseases of chili INIFAP (22), in Aguas Calientes State, Mexico, chili's wilt is caused by fungi of the genera Rhizoctonia sp., Fusarium spp and Phytophthora spp. and its presence was registered in all producing states of the country.

The economic incidence and importance of a disease depend on various factors such as: settling capacity, penetration, colonization and dissemination of the pathogen in the host (2). Similarly, other important factors must be considered such as: agronomic handling of the plant, type of cultivation, sowing season, type of soil, watering, fertilization, nearby crops and environmental factors in the crop (25).

In Ecuador, there are few studies about the main diseases affecting pepper. This is a limitation in the setting of plant protection control measures. The main objective of this study was to evaluate the effect of "pata seca" on pepper commercial plantations during 2013 and 2014, as well as the implementation of measures that will prevent economic loss to farmers. Due to the relevance of the crop and the mentioned background, this study was conducted during 2013 and 2014 in pepper production areas of Guayas and Santa Elena Provinces. The main purpose was to determine and identify the presence of the causal agent associated with "pata seca". The field condition and the farmer's handling of the vegetable were also determined.

\section{MATERIALS AND METHODS}

\section{"Pata seca" diagnosis in pepper farms}

During 2013 and 2014, we continually visited 23 pepper producers in the parish of Yaguachi Viejo GAD-Yaguachi (13) in Guayas Province; other places from Santa Elena Province were also included in the coastal profile of Ecuador. The collected data were: name of the owner, area surface, type of used seedling, type of grown seed and cultivar/hybrid, type of irrigation, water quality, crop soil management, sanitary problems and type of cultivation (organic or conventional). The incidence of plants affected with "pata seca" symptoms was recorded according to the producing area. In each farm, between 200 and 500 pepper plants were evaluated. For correct recognition of symptomatology, specialized field manuals were used $(24,25,30)$.

\section{Isolation and identification of fungi associated with "pata} seca" in pepper

In each farm, three samples were collected from plants presenting "pata seca" symptoms (two plants per sample). The samples were stored in properly labeled plastic bags and taken to the laboratory for processing. For each sample, the roots had the attached soil removed and were carefully washed with water. Subsequently, five fragments of root and collar tissue were cut from the plant and disinfected with sodium hypochlorite at $1.5 \%$ for 1 and 2 minutes. Then, the plant tissue fragments were cleaned with sterile distilled water, dried with sterilized filter paper and transferred to Petri dishes, which contained acidified PDA growth medium (Merk). Petri dishes were incubated at $28^{\circ} \mathrm{C}$ and 12-hour photoperiod for seven days $(1,8,9)$. Once developed, fungal colonies were purified in the cultivation medium for identification $(4,6,10)$.

Pathogenicity tests and isolation of Sclerotium rolfsii and Fusarium spp. associated with "pata seca" symptoms

Pathogenicity tests were conducted with three $F$. oxysporum isolates, two $F$. solani isolates and five $S$. rolfsii isolates to complete Koch's postulates (Table 1).
Table 1. Fungal isolates from pepper plants showing "pata seca" symptoms.

\begin{tabular}{lll}
\hline Isolates & Fungi & Farmer \\
\hline F-2 & Fusarium solani & Sr. Salazar \\
F-3 & F. oxysporum & Ensayo Vuelta Larga \\
F-4 & F. oxysporum & Sr. Cedeño \\
F-5 & F. solani & Sr. Zambrano \\
Scl-1 & Sclerotium rolfsii & Sres. Hnos Vera \\
Scl-2 & S. rolfsii & Sres. Hnos Vera \\
Scl-3 & S. rolfsii & Sr. Armijos \\
Scl-4 & S. rolfsii & Sr. Arreaga \\
Scl-5 & S. rolfsii & Ensayo Vuelta Larga \\
\hline
\end{tabular}

For pathogenicity tests, seedlings of Quetzal hybrid were placed on trays containing organic substrate composed of a mixture between coffee husk (50\%) and clay $(50 \%)$ which was previously sterilized in an autoclave. After 25-30 days of emergency, some seedlings were inoculated with Fusarium spp. and others with $S$. rolfsii. For Fusarium spp. inoculation, the inoculum was obtained in PDA medium and incubated during 14 days at $25^{\circ} \mathrm{C}$ and 12 -hour photoperiod $(8,26)$. Once pure colonies were obtained, conidial suspensions were prepared at a concentration of $10^{6}$ conidia $\mathrm{mL}^{-1}$. The resulting suspension was filtered in two-layer gauze (8). The root system of pepper seedlings was immersed during 5 minutes in conidial suspension and immediately transplanted to $1-\mathrm{kg}$ plastic pots, which contained the sterilized substrate. The experiment was installed in a completely randomized design, in which four plants were inoculated and transplanted, with six replicates and 24 plants for each treatment or isolation. For inoculation with $S$. rolfsii isolates, the colonies were previously cultivated during 21 days, at $25{ }^{\circ} \mathrm{C}$, until the grown sclerotia had dark coloration (18). Inoculations were performed by depositing three small portions of fungal structure and sclerotia cultivated in culture medium at the level of the collar region in each base of the plants (15). Control treatment was inoculated by submerging the roots in sterile distilled water and placing PDA medium fragments at the same level of the collar region of plants. The plants were kept in a greenhouse, at $24-27^{\circ} \mathrm{C}$, receiving adequate irrigation and fertilization. The disease symptoms were evaluated after inoculation, at 50 days after transplanting. The total number of diseased plants was recorded and the percentage of diseased plants was calculated.

\section{RESULTS AND DISCUSSION}

\section{"Pata seca" diagnosis in pepper cultivation}

The sampling area of this study was 12.2 hectares under cultivation. Most pepper production in this area is performed by small farmers, who own between 0.5 a 3 ha. Approximately $78 \%$ and $22 \%$ farmers grow seedlings in the soil and in plastic trays, respectively. Around $82 \%$ farmers irrigate the crop by means of gravity and only $18 \%$ use drop irrigation. All farmers have conventional crop production. About 69 farmers are visited by technicians from enterprises of chemical products and $29 \%$ are visited by extension officers from 
public institutions. Only $4.34 \%$ farmers do not receive any technical visit. There were 13 types of pepper cultivars, the seeds of which were imported from other countries (3). The most used cultivars in the researched area were: Quetzal (43.5\%), Salvador (39.1\%) and Nathalie (17.4\%). Due to the high cost of seeds and other technical reasons, all farmers use recycled seeds from those hybrids for their cash crops. They obtain the recycled seeds from their best peppers, which are selected in the harvest period. The recycled seeds belong to the first or second generation of the grown hybrid. This implies genetic segregation. Consequently, those new generations will not have the desired uniform characteristics of the original pepper plants. The highest occurrence of "pata seca" was found for pepper plants from seeds that were recycled from the hybrid Salvador $(41.4 \%)$, followed by the hybrids Quetzal $(27.4 \%)$ and Nathalie $(21.1 \%)$ (Table 2). According to information received from the farmers at these communities, there are times of the year when the farm production loss is total, caused by the high incidence of "pata seca".

\section{Identification of the etiological agent of "pata seca"}

"Pata seca" is a disease that occurs in pepper crops after the first flowering period until fruit production (approximately 40 days after transplanting) and remains until the final cycle of the crop. Frequently, due to the farmers' lack of knowledge, the diseased plants remain in the field and act as inoculum source for the following crops. As confirmed by this study, "pata seca" symptoms start as a brown spot in the collar region. It produces a color change in parts of the plants. The leaves change from green to yellow. Then, they turn to light brown and start to wilt, which becomes widespread and leads the plant to death. The fruits of the affected plants, in any growth stage, ripen rapidly. Depending on the environmental conditions, those plants rot. Thus, roots decrease in number and acquire a brown coloration with necrosis and advanced rot state from the collar region of the plant to the end of the main root. Therefore, when the basal portion of the stem is cut, the cortical region is darkened. Sometimes, in the basal portion of the stem, there is a white mycelium layer. Similarly, its appearance is cottony and there are brown sclerotia over it (Figure 1). The mentioned symptoms are similar to those previously described $(5,30)$ for wilt in pepper crops caused by Fusarium spp. and $S$. rolfsii.

Of 386 isolations, the prevalence in 2013 and 2014, respectively, was $31.17 \%$ and $49.64 \%$ for S. rofsii, $29.29 \%$ and $32.37 \%$ for Fusarium spp., and $44.54 \%$ and $17.99 \%$ for other fungi.

Identification of fungi was based on the listed distinctive morphologic characteristics $(4,6,10,28)$.

Table 2 - Incidence of "pata seca" in pepper production areas: Yaguachi Viejo Parish and Santa Elena Peninsula, Ecuador.

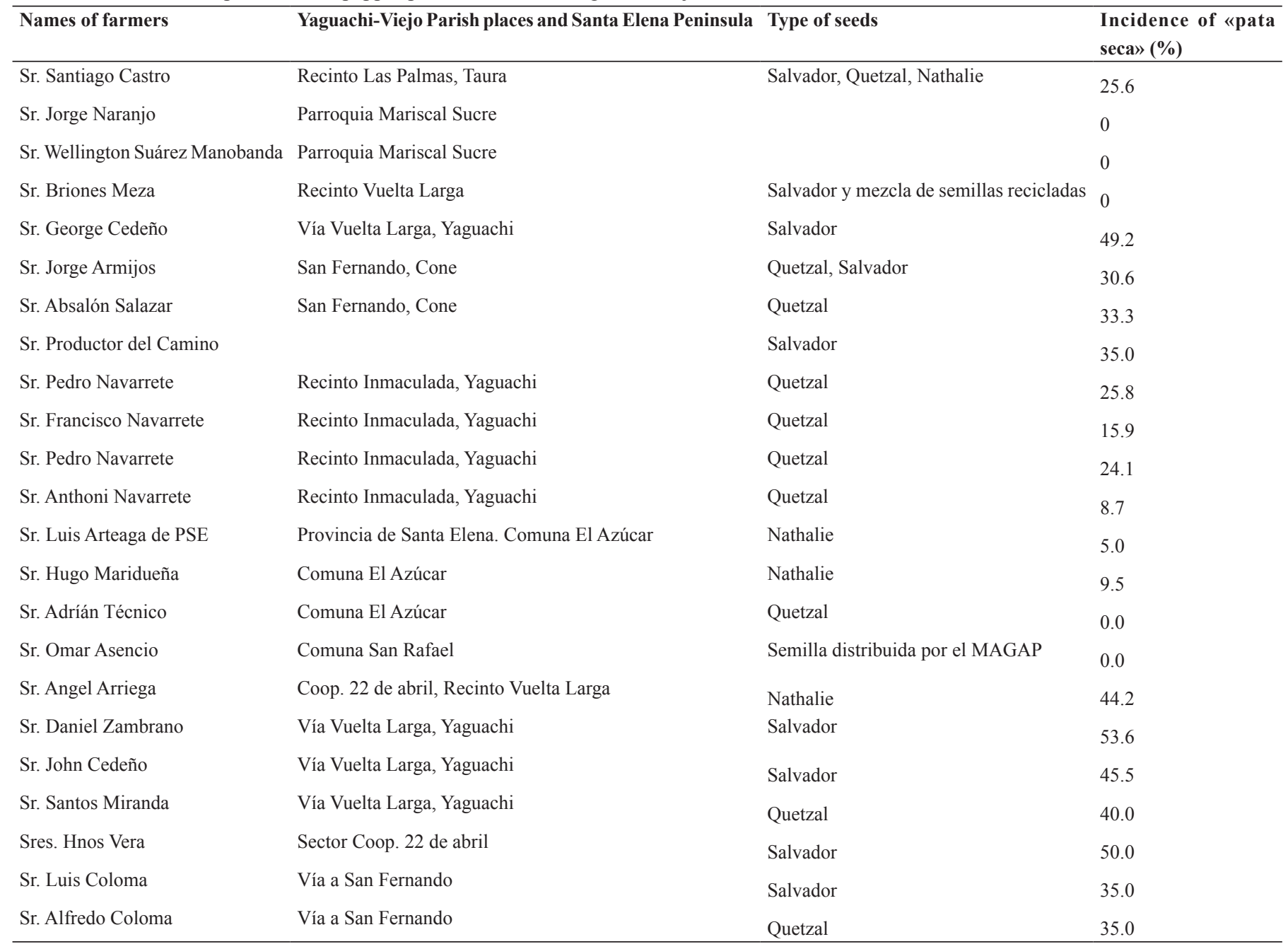



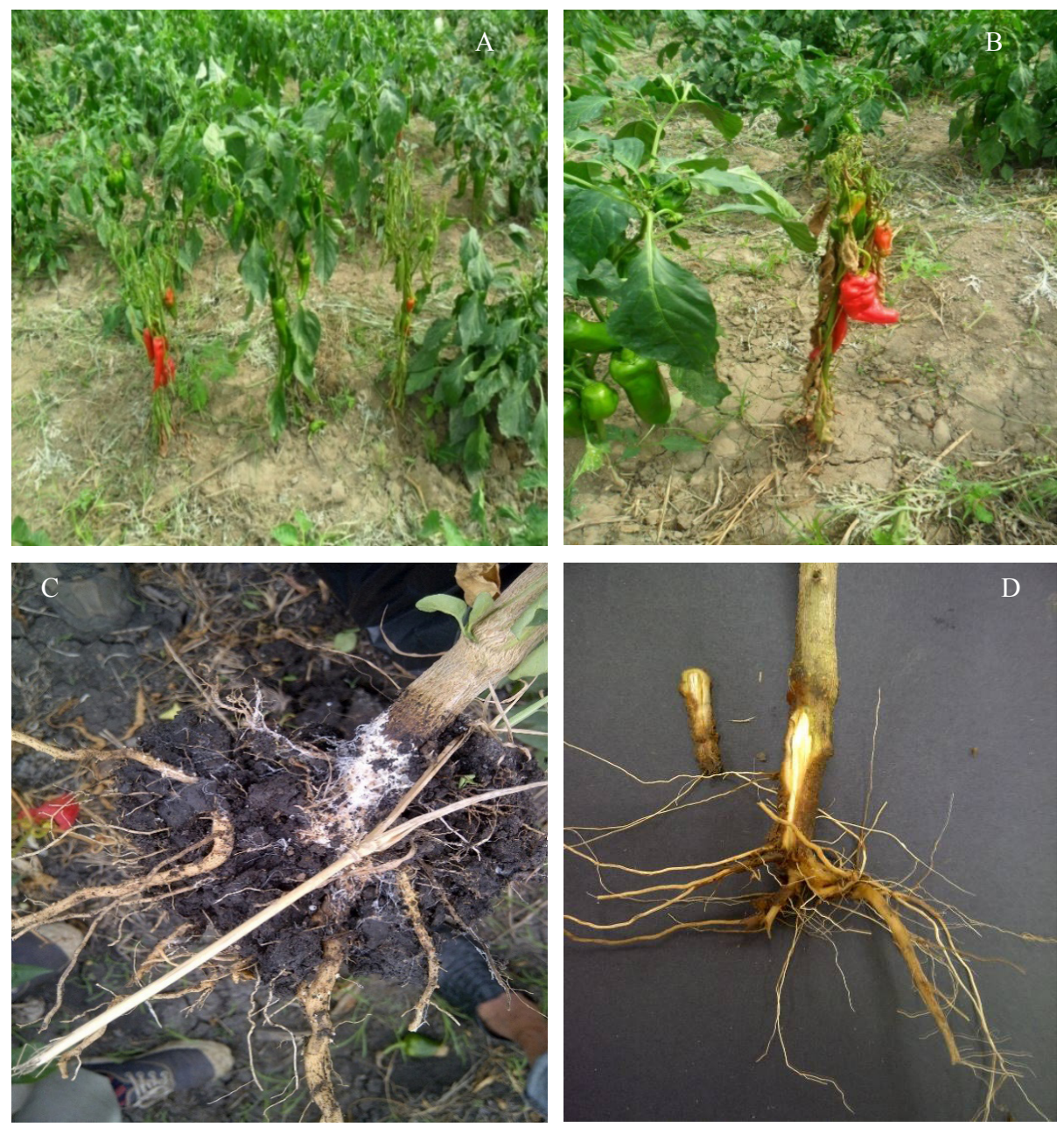

Figure 1. A) Pepper plants with symptoms of "pata seca"; B) Pepper plants with advanced symptoms of "pata seca"; C) Presence of white mycelium and sclerotia; D) Darkening of the cortical base of the stem.

Colonies identified as Sclerotium sp. presented white pale mycelium that grows rapidly without conidia, septate-branched hyphae and fibulas, as well as hard, round, light brown sclerotia. Fusarium spp. colonies exhibit purple mycelium, which is pale yellow or brown with septate hyphae, macroconidia and chlamydospores. Conidia are produced as long and short phialides, depending on the species. Based on these characteristics described by Booth (6), the identified species were $F$. oxysporum and $F$. solani.

The obtained results and the high frequency of isolation of S. rolfsii and Fusarium spp. from pepper plants with "pata seca" symptoms suggest that these species are associated with "pata seca" disease. Consequently, plants die and fruits ripe early, losing their quality for marketing. The results obtained in this study and the identification of Fusarium spp. in pepper crops corroborate the results obtained by Pontis (31), who identified this genus as the cause of pepper wilt in Argentina. Similarly, these results agree with those described by Roberts $e t$ al. (36), who mentioned the presence of this disease in the United States, Mexico and Italy. In Mexico, researchers have identified F. oxysporum and $F$. solani associated with chili's wilt in Guanajuato State INIFAP (21), where the described symptoms correspond to those reported in this study. This means that pepper plants affected by Fusarium spp. are attacked in the flowering and fruiting stage. Afterwards, the plants die.

Pathogenicity of Fusarium spp. and S. rofsii isolates in pepper plants

The first symptoms of the disease started after 50 days of plant inoculation. The plants presented yellowish discoloration from the basal to the top leaves. Then, the plants showed symptoms of generalized withering, resulting in death. The color of the stem varied from green to reddish brown with black spots on the external part. The roots were rotten and ill developed (Figure. 2). The major incidence of the disease in the Quetzal hybrid plant inoculated with S. rolfsii was $2.5 \%$ (Scl-1) and $7.5 \%$ (Scl-4). The extent of the disease was highest with the isolates Scl-5 (26\%) and Scl-3 (37\%). Only $21.67 \%$ of 120 plants inoculated with $S$. rolfsii died, regardless of the type of isolates. The major incidence of affected plants, during the experiment, was found for the isolates Scl-3 and Scl-4 (Figure 3).

In plants inoculated with Fusarium spp., only isolates F-2 and F-5, corresponding to $F$. solani, were pathogenic: $1.7 \%$ and $3.3 \%$, respectively. Based on these results, $F$. solani is an agent related to "pata seca" symptoms but is not the main agent because these symptoms were similar to those observed with $S$. rolfsii in plants under field conditions.

Although the plants barely showed a significant incidence, the disease could be replicated under greenhouse condition. Therefore, the main causal agent was suggested to be $S$. rolfsii, related or not to $F$. solani, and possibly to another fungus isolated in this study. Regarding Fusarium spp., Palazón and Palazón (29) reported that it was the causal agent of "tristeza" and that attempts to inoculate this 

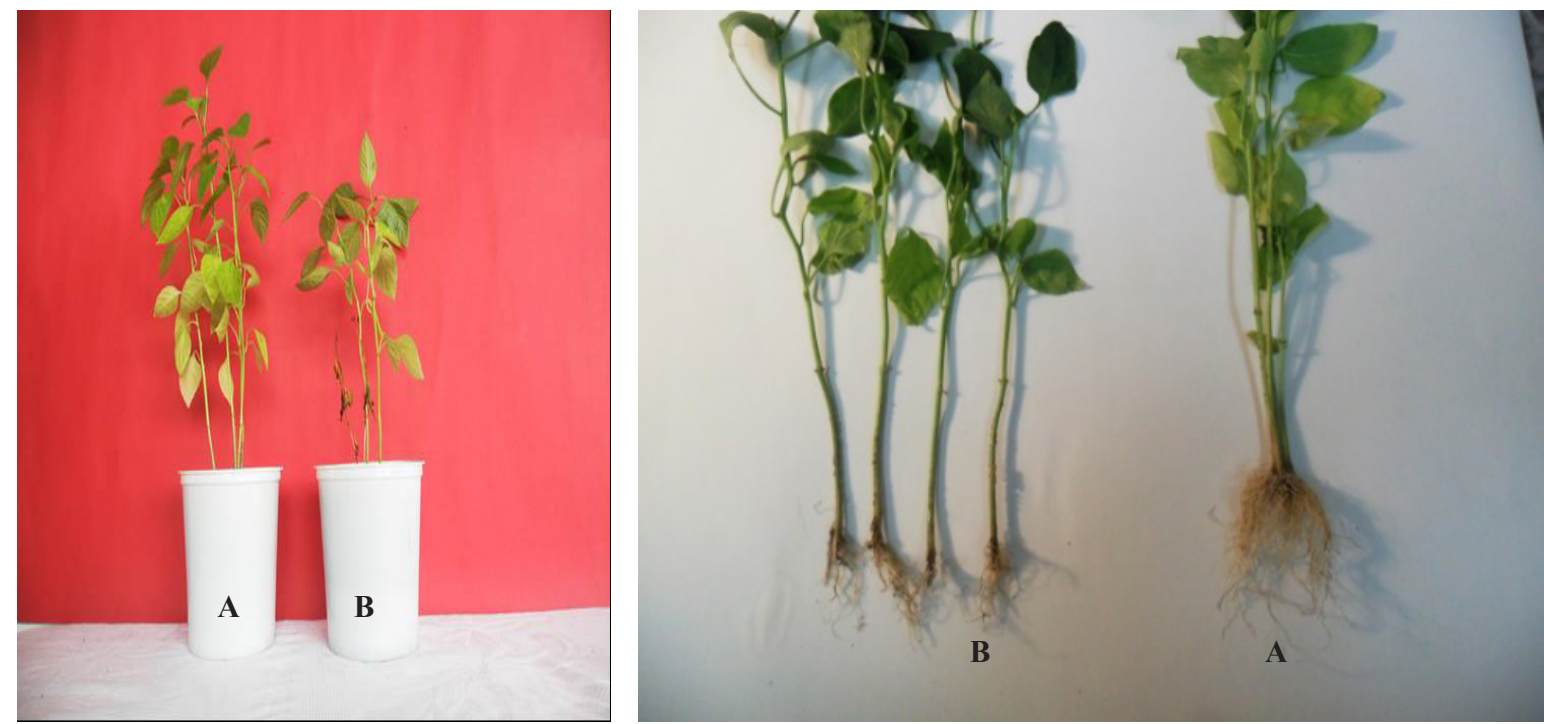

Figure 2. A) Non-inoculated plants; B) Plants inoculated with Sclerotium rolfsii and symptoms of "pata seca".

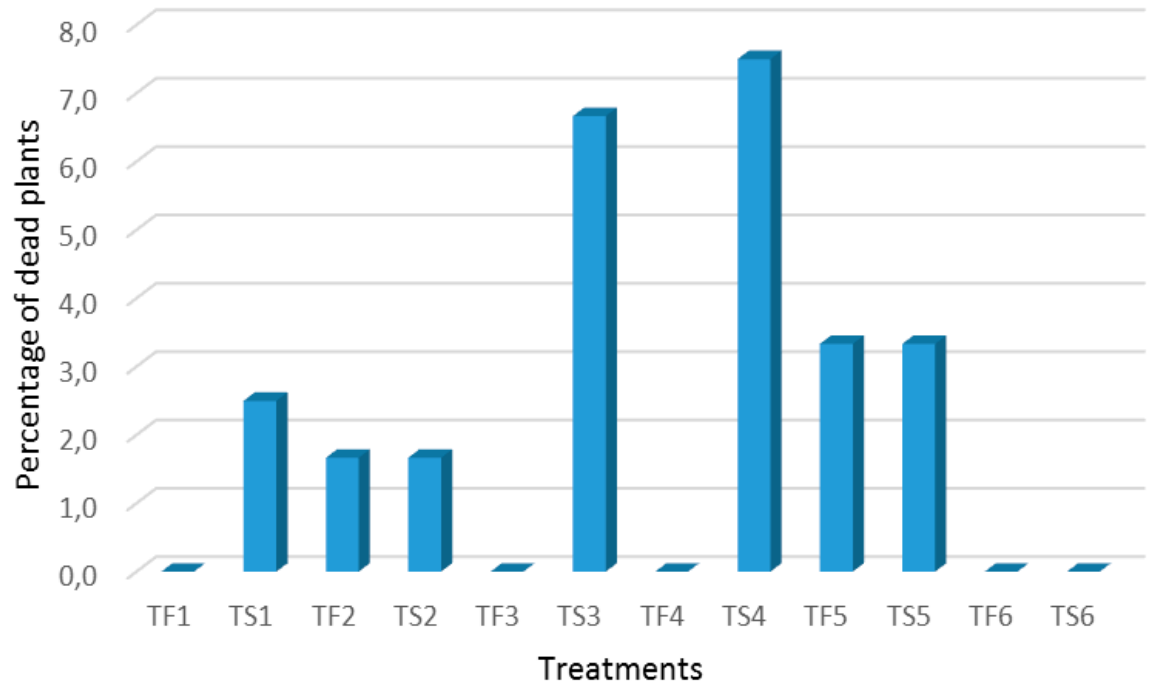

Figure 3. Percentage of dead plants according to the pathogenicity test.

pathogen were unlikely to succeed. INIFAP (21) stated that Fusarium species instead acted as saprophytic jointly with other causal agents; in Mexico, "marchitez del chile" and its effect were favored by the mechanical damage of pests or other pathogens.

No study similar to the present one about pathogenicity of isolates in pepper crop and symptomatology is available in Ecuador INIAP (20). However, Capuz (7) worked with Trichoderma sp. and reported the presence of $S$. rolfsii in tomatoes and pepper samples in Yaguachi.

The Sclerotium species was described by Saccardo in 1891 and is one of the most destructive fungi for pepper crops in warm and humid zones all over the world (35). It shows rapid mycelial growth with no sporulation, forming different types of hard structures called sclerotia. This is one of the most important fungi all over the world, showing great diversity of hosts and ecological distribution (33).

Pathogenicity results, related to those observed for $S$. rolfsii, agreed with those reported by Gonzalez et al. (15) for corn crops inoculated with a sample of tissue with mycelia and sclerotia. These also agreed with the results reported by Galmarini et al. (14), who observed symptoms in orchid plants inoculated with $S$. rolfsii.

The different virulence among $S$. rolfsii species could be associated with rapid growth and development of significant amount of endopolygalacturonase and oxalic acid Punja (32).

\section{REFERENCES}

1. Alfenas, C.A.; Ferreira, A.F.; Mafia, G.R.; Gonçalves, C.R. Isolamento de fungos fitopatogênicos. In: Alfenas, C.A.; Mafia, G.R. (Ed.). Métodos de Fitopatologia. Viçosa: UFV, 2007. p.53-90

2. Agrios, G.N. Plant pathology. 5th ed. Amsterdam: Elsevier Academic Press, 2005

3. AGROCALIDAD. Listado de registro de semillas y empresas importadoras del Ecuador 2014. Quito: Agrocalidad, 2013. Available at: <http://www. agrocalidad.gob.ec $>$. Accessed on: 7 Aug. 2015.

4. Barnett, H.L.; Hunter, B.B. Illustrated Genera of Imperfect Fungi. Minnesota: The American Phytopathological Society, 1998. 218p. 
5. Black, L.L.; Green, K.S.; Hartman, G.L.; Poulos, M.J. Pepper diseases: a field guide. Taipei: Asian Vegetable Research and Development Center, 1993.

6. Booth, C. Fusarium Laboratory Guide to the Identification of The Mayor Species. England: Commonwealth Mycological Institute, 1977.

7. Capuz, E.R. Identificación de microorganismos antagonistas de fitopatógenos de suelo y su efecto in vitro e invernadero en especies hortícolas. 2009. 68p. Tesis (Grado de Ingeniería Agronómica)-Universidad Estatal de Guayaquil, Guayaquil.

8. Castellanos, G.; Jara, C.; Mosquera, G. Guías prácticas de laboratorio para el manejo de patógenos del frijol. Cali: Centro Internacional de Agricultura Tropical, 2011. 232p. (Publicación CIAT, 375).

9. Dhingra, O.; Sinclair, J. Basic plant pathology methods. Florida: CRC Pres, 1987.

10. Dugan, M.F. The identification of fungi: an iilustrated introduction with keys, glosary, and guide to literature. St. Paul: The American Phytothological Society, 2006.

11. Faostat. Principales países productores de pimiento. Roma: FAO, 2012. Available at: <http://faostat.fao.org/>. Accessed on: 6 Aug. 2015.

12. Faostat. Productividad del cultivo de pimiento. Roma: FAO, 2013. Available at: <http://faostat.fao.org/>. Accessed on: 6 Aug. 2015.

13. Gobierno Autónomo Descentralizado Municipal de San Jacinto de Yaguachi - GAD-Yaguachi. Plan de desarrollo y ordenamiento territorial 20122019. Guayaquil: Fundación Santiago de Guayaquil, 2012. 149p.

14. Galmarini, R.M.; Cabrera, G.M.; Flachsland, E. Sclerotum rolfsii nuevo Patógeno de orquídeas para la República Argentina. In: Abstracts XXXIV Congresso Brasileiro de Fitopatologia. XI Congresso Latinoamericano de Fitopatologia, São Pedro, São Paulo, Brazil. Anais do XXXIV Congresso Brasileiro de Fitopatologia, 2001.

15. González, A.; Labrin, N.; Barrientos, V.; Alezones, J. Primer reporte de Sclerotium rolffsii como agente causal de las pudriciones del talo y la mazorca del maíz en Portuguesa, Venezuela. Fitopatología Venezolana, Maracay, v.21, p.23-25, 2008.

16. Holguín, M.P. Estudio de prefactibilidad para la producción de pimiento en la Península de Santa Elena. 2012. 268p. Tesis de Ingeniería Comercial)-Facultad de Ciencias Humanística e Económica, Escuela Superior Politécnica del Litoral, Guayaquil.

17. Huang, H.C.; Vallad, E.G. Crow and root diseases of pepper. In: Russo, V.M. (Ed.). Pepper: botany, production and uses. Oxfordshire: CAB Internacional, 2012. p.203-215.

18. Hyeuk, K.J.; Chang-Seuk, P. Stem Rot of Tomato Caused by Sclerotium rolfsii in Korea. Mycobiology. 30. 244. 2002. Available at: <www.mycobiology.or.kr/Synapse/Data/PDFData>. Accessed on: 15 May 2015.

19. INAMHI. El cultivo del pimiento y el clima en el Ecuador. Quito. INAMHI, 2013. Available at: $<$ http:// www.serviciometeorologico.gob.ec $>$. Accessed on: 15 May 2015.

20. INIAP. Manual Agrícola de los Principales Cultivos del Ecuador. Quito:
INIAP, 1987. (Manual, 10).

21. INIFAP. Guía para el manejo de la marchitez del Chile en Guanajuato. Jalisco: Editora Prometeos, 2009. Available at: <www.inifap.gob.mx $>$. Accessed on: 8 July 2015.

22. INIFAP. Nueva Tecnología de Manejo para el Control de la Marchitez del Chile en Aguascalientes. Aguas Calientes: Centro de Investigación Regional Norte Centro, Campo Experimental Pabellón, 2010. Available at: <http:// biblioteca.inifap.gob.mx>. Accessed on: 8 July 2015.

23. INEC. Actualización del Marco de Muestreo de la Encuesta de Superficie y Producción Agropecuaria. Quito, 2014. Available at: $<$ http://www.ecua dorencifras.gob.ec/>. Accessed on: 6 Mar. 2015.

24. Koike, T.S.; Gladders, P.; Paulus, O.A. Vegetables diseases: a color handbook. Boston: Academic Press, 2007.

25. Lopes, C.A.; Ávila, A.C. Doenças do pimentão: diagnose e controle. Brasília, DF: Embrapa Hortaliças, 2003.

26. Mendes, M.P. Caracterização, toxicidade e patogenicidade de Fusarium spp. em genótipos de soja em sistema plantio direto. 2009. 91p. Dissertação (Mestrado em Agronomia/Produção Vegetal)-Universidade Federal de Santa Maria, Santa María.

27. Mullen, J. Southern Blight, southern stem blight, white mold: the plant health instructor. Saint Paul, Minnesota: The American Phytopathological Society, 2006. Available at: $<$ http://www.apsnet.com/>. Accessed on: 2 May 2014

28. Nelson, P.E.; Toussoun, T.; Marasas, W. Fusarium species: an illustrated manual for identification. Pennsylvania: University Press, 1983.

29. Palazón, C.; Palazón, I. Estudios epidemiológicos sobre la tristeza del pimiento en la zona de valle del Ebro. Boletín de Sanidad Vegetal, Plagas, v.15, p.233-262, 1989.

30. Pernezny, K.; Roberts, P.D.; Murphy, J.F.; Goldberg, N.P. Compendium of Pepper Diseases. St. Paul: The American Phytopathological Society, 2009.

31. Pontis, E.R. El "marchitamiento" del pimiento (Capsicum annuum) en la provincia de Mendoza. Rev. Argentina de Agronomía, Buenos Aires, v.7, n.2, p.113-127, 1940 .

32. Punja, Z.K. The biology, ecology, and control of Sclerotium rolfsii. Annual Review of Phytopathology, Palo Alto, v.23, p.97-127, 1985.

33. Punja, Z.K.; Rahe, E.J. Sclerotium. In: Singleton, L.L.; Mihail, J.D.; Rush, C.M. (Ed.). Methods for research on soilborne phytopathogenic fungi. St. Paul: American Phytopathological Society Press, 1992. p.166-171.

34. Quilambaqui, J.M. Doenças do pimentão em regiões produtoras do Equador: identificação e manejo da "Pata seca" e ocorrência de viroses. 2015. 56p. Tese (Doutorado em Agronomía)-Faculdade de Ciências Agronômicas de Botucatu, Universidade Estadual Paulista, Botucatu.

35. Revelli, V (1989) A wilt of pepper incited by Fusarium oxysporum f.sp. capsici formsa specialis nova. MSc thesis. Lousiana State University.

36. Roberts, P.D.; Adkins, S.; Pernezny, K.; Jones, J.B. Diseases of pepper and their management. In: Naqvi, S.A.M.H. (Ed.). Diseases of fruits and vegetables. Amsterdam: Academic Publishers, 2004. p.333-387 